\title{
THE MALE OF THE AMPHIPOD HAUSTORIUS ARENARIUS SLABBER
}

\author{
By Emrys Watkin, Ph.D., D.Sc. \\ University College of Wales, Aberystwyth
}

The amphipod Haustorius arenarius has been recorded by several workers as an inhabitant of the intertidal and shallow-water sands of the coasts of Britain, its characteristic shape being regarded as an adaptation to its habit of burrowing in the sand. Sars (1895) describes the female only, and Stebbing (1906) summarizes the description given by Sars. Chevreux \& Fage (1925) record the species from numerous localities on the coast of France and give in addition the Kattegat, Holland, Great Britain and the east coast of North America as the extent of its distribution. They state that the male is unknown. This apparent absence of the male of the species formed a notable exception amongst the Amphipoda, a group in which the males may usually be distinguished from the females by a number of secondary sexual characters of which the brood lamellae of the adult female is the most characteristic.

Sexton (1925), in her study of the growth, moulting and mating habits of species in the genus Gammarus, has shown that the brood lamellae develop gradually, increasing in size through a series of moults and finally becoming fully formed by the development of long fringing hairs. Once formed the lamellae remain a constant feature at each moult. Hart (1930) shows that such a mode of development also occurs in Corophium volutator. Unwin (1920) has shown that in the isopod Asellus aquaticus the brood lamellae appear suddenly at the ecdysis accompanying fertilization and disappear at the moult which succeeds the release of the young from the pouch. Sheppard (1927) draws attention to this distinction between Asellus and Gammarus as one which may prove to be constant throughout the two groups.

Dennell (1934), in his study of the habits and feeding mechanism of Haustorius arenarius, states (p. 374): ' Of the I2O specimens examined all were females possessing oostegites, or lacking them, but resembling those so provided in all other respects'; and also p. 375, 'Whether reproduction takes place parthenogenetically or whether there may be a male of the species is unsettled'.

These remarks of Dennell suggested to me that the 'females lacking oostegites' were males. To test this assumption a collection of $H$. arenarius from the estuary of the river Dovey was examined and grouped on the presence or absence of brood lamellae. Of the fifty individuals which formed the sample twenty-five showed brood lamellae in various stages of develop- 
ment as described by Sexton in the genus Gammarus. This group varied in total length from 5 to I4 mm., and a number of those II $\mathrm{mm}$. and over carried eggs in the brood pouch. Of the remaining twenty-five, varying in length from 5 to ro mm., a number were dissected and sectioned. All showed a male reproductive system which, as is usual in amphipods, lay dorsal to the alimentary canal and its associated diverticulae. The system consists of an anterior testis portion which narrows to a vas deferens on which a swollen receptaculum seminis occurs which opens at the base of the seventh segment of the mesosome.

This sample was collected in July. A further sample collected in December showed the same general features except that no egg-bearing females were obtained and the brood lamellae were without the fringing hairs. In each case no individual less than $5 \mathrm{~mm}$. in length was obtained. A collection of Haustorius arenarius from Kames Bay gave individuals of 3 and $4 \mathrm{~mm}$. total length, none of which size bore developing brood lamellae. It thus appears that the brood lamellae begin to form at a size of about $5 \mathrm{~mm}$.

A comparison of the appendages of the adult males and females, particularly of those which show secondary sex differences in other amphipods, namely, the antennules and antennae, the first and second gnathopods and the third uropods, failed to show a single morphological difference. The related genera in the family Haustoriidae, Bathyporeia and Urothoë, show a secondary sex difference in the length of the flagellum of the antenna which is long and bears calceoli in the male and is short and without calceoli in the female. No such distinction occurs in Haustorius. Sexton \& Spooner (I940) have shown that in the genus Marinogammarus the males bear special sensory setae, particularly on the antenna. I was unable to distinguish any differences in the setal armature of the male and female of Haustorius.

\section{SUMMARY}

The male of Haustorius arenarius is identical with the female in all external morphological characters apart from the absence of brood lamellae. The females develop brood lamellae at $5 \mathrm{~mm}$. total length, eggs appear in the brood pouch at II mm., and they may reach a length of I4 $\mathrm{mm}$. The largest male obtained measured Io $\mathrm{mm}$.

\section{REFERENCES}

Chevreux, Ed. \& Fage, L., 1925. Faune de France. Amphipodes, Vol. Ix, p. 95. Paris. DenNell, R., 1934. The habits and feeding mechanism of the amphipod Haustorius arenarius. Fourn. Linn. Soc., Vol. xxxvIII, pp. 363-88.

Hart, T. J., I930. Preliminary notes on the bionomics of the amphipod, Corophium volutator Pallas. Fourn. Mar. Biol. Assoc., Vol. xvi, pp. 76I-89.

SARs, G. O., I895. An account of the Crustacea of Norway. Vol. I, Amphipoda, p. I35. Kristiania. 
Sexton, E. L., I925. The moulting and growth stages of Gammarus with descriptions of the normals and intersexes of Gammarus chevreuxi. Fourn. Mar. Biol. Assoc., Vol. xII, pp. 340-64.

Sexton, E. L. \& SPOoner, G. M., I940. An account of Marinogammarus (Schellenberg) gen. nov. [amphipoda], with a description of a new species, M. pirloti. Fourn. Mar. Biol. Assoc., Vol. xxiv, pp. 633-82.

SHEPPARD, E. M., I927. Revision of the family Phreatocidae (Crustacea), with a description of two new species. Proc. Zool. Soc. London, April I927, pp. 8I-I24. Stebbing, T. R. R., I906. Amphipoder. I. Gammaridea. Das Tierreich., Leif. 21, p. 125 .

Unwin, E. E., I920. Notes on the reproduction of Asellus aquaticus. Fourn. Linn. Soc., Vol. xxxIv, pp. 335-43. 